OPEN ACCESS

Edited by:

Nicola La Porta,

Fondazione Edmund Mach, Italy

Reviewed by:

Miguel Montoro Girona,

Université du Québec en Abitibi

Témiscamingue, Canada

Melinda Halassy,

Hungarian Academy of Science,

Hungary

${ }^{*}$ Correspondence:

Katharina Lapin

katharina.lapin@bfw.gv.at

Specialty section:

This article was submitted to Functional Plant Ecology,

a section of the journal

Frontiers in Plant Science

Received: 13 January 2020

Accepted: 17 August 2020

Published: 03 September 2020

Citation:

Langmaier M and Lapin K (2020)

A Systematic Review of the Impact of Invasive

Alien Plants on Forest

Regeneration in European

Temperate Forests.

Front. Plant Sci. 11:524969. doi: 10.3389/fp/s.2020.524969

\section{A Systematic Review of the Impact of Invasive Alien Plants on Forest Regeneration in European Temperate Forests}

\author{
Magdalena Langmaier ${ }^{1,2}$ and Katharina Lapin ${ }^{1 *}$ \\ ${ }^{1}$ Austrian Federal Research Centre for Forests, Natural Hazards and Landscape, Vienna, Austria, ${ }^{2}$ Institute of Silviculture, \\ University of Natural Resources and Life Sciences Vienna, Vienna, Austria
}

Invasive alien species (IAS) are one of the major threats to global and local biodiversity. In forest ecosystems, the threats caused by IAS include hybridization, transmission of diseases and species competition. This review sets out to analyze the impact of alien plant species on forest regeneration, which we consider to be one of the key stages in tree ecology for the survival of forest ecosystems in the future. The focus of the study is directly relevant to practitioners, forest managers and the conservation management of forests. With this systematic review, we aim to provide an overview of 48 research studies reporting on the impact and/or management of IAS in European temperate forests. We followed a multi-step protocol for compiling the publications for the literature review, with nine search queries producing a total of 3,825 hits. After several reduction rounds, we ended up with a grand total of 48 papers. We identified 53 vascular plant species having a negative influence on forest regeneration in Central European forests. In total, 21 tree species are reported to be impacted by IAS in 24 studies. The results of the review synthesis show that five impact mechanisms affect the regeneration success of native tree species: competition for resources, chemical impact on regeneration, physical impact on regeneration, structural impact on regeneration and indirect impact through interaction with other species. We identified in our synthesis management measures that have been recommended for application at different stages of biological invasions. The associated costs and required resources of management measures are under-reported or not accessible by reviewing the scientific literature. We can thus conclude that it is very import to improve the links between science and practical forest management. We expect that this review will provide direction for invasive plant species research and management aimed at protecting biodiversity in European temperate forest ecosystems.

Keywords: biological invasion, exotic plants, forest dynamics, ground vegetation, invasive species management, neophytes, rejuvenation, tree seedlings 


\section{INTRODUCTION}

\section{Background}

Invasive alien or non-native plant species (hereinafter: IAS sensu Pyšek et al., 2004) are one of the major threats to global and local biodiversity (IUCN Council, 2000). In addition, biological invasions have negative socio-economic and human health impacts (Howe and Smallwood, 1982; Villamagna and Murphy, 2010; Shackleton et al., 2018; Potgieter et al., 2019; Roy et al., 2019). The rapid spread of few IAS in forests was mediated by the positive socio-economic effects of potentially invasive plant species in urban and rural areas (Kowarik, 2010; Vaz et al., 2017; Vaz et al., 2018; Castro-Díez et al., 2019). Therefore, several policies, risk assessments and legislations are now in place to regulate the spread of IAS in forest ecosystems (Heywood and Brunel, 2009; Brundu and Richardson, 2016; Pötzelsberger et al., 2020). The threats caused by IAS in forest ecosystems include hybridization, transmission of diseases and species competition (Knapp and Canham, 2000; Ashton et al., 2005; Vilà et al., 2011; Medvecká et al., 2018). The establishment and spread of alien plants in temperate forest ecosystems have not been widely considered until recently (Essl et al., 2011; Wagner et al., 2017), and European temperate broadleaf and mixed forests in particular were previously considered less affected than other landcover types (Chytrý et al., 2009; Martin et al., 2009). However, an increasing number of studies now indicate that temperate forests as well as other forest biomes might not be as resilient as previously assumed (McEwan et al., 2009; Dreiss and Volin, 2013). In boreal forests, for instance, an ongoing invasion of alien plants was detected, despite the relatively low levels of anthropogenic disturbance (Sanderson et al., 2012).

A key component of biological invasions are human activities that modulate the introduction and spread of alien species, and a large number of human activities supporting the spread of alien plant species have been identified (Richardson et al., 2000; Richardson et al., 2007). Clearing, for example, may change light conditions and resource availability in ways that favour alien plant species. Furthermore, the construction of forest roads can promote the spread of alien plant seeds and specimens through the movement of contaminated soil and construction material (Joly et al., 2011; Muscolo et al., 2014; Kerri et al., 2016). Since the forest road system in European temperate forests is well-developed, the risk of forest roads functioning as pathways for invasion should not be underestimated (Woziwoda et al., 2018).

Besides human-mediated disturbances, natural disturbances are also increasing due to climate change. Events such as storms, flooding and forest fires provide alien plants with opportunities to invade temperate forests (Hobbs and Huenneke, 1992; Brooks et al., 2004; Lake and Leishman, 2004). The spread of IAS driven by disturbances is frequently linked to poor individual performance and reduced species diversity, which lead to irreversible changes in the species composition of understory vegetation (Sjöman et al., 2016; Seidl et al., 2017; Navarro et al., 2018). For example, a proliferation of shade-tolerant alien plant species such as Impatiens parviflora has been observed at many sites in European temperate broadleaf forests (Chmura and Sierka, 2007; Hejda, 2012; Jarčuška et al., 2016; Lapin et al., 2019). These changes in the species composition of understory may impact the competition between IAS and native species and affect site conditions. We argue that alien plant species may be influencing the successful regeneration of tree seedlings.

Forest managers distinguish between two types of regeneration (also referred to as rejuvenation), meaning the process by which forests are renewed: natural and artificial regeneration. Natural regeneration is based on recruitment deriving from seeds (seedlings) without human assistance, while artificial regeneration implies the planting of seedlings or the sowing of seeds. The regeneration process of forest trees occurs in different phases: a seedling phase, a juvenile intensive height growth phase and a maturity phase (Borghetti and Giannini, 2009). The success of both natural and artificial regeneration in European temperate forests is affected by a large number of biotic and abiotic factors. Gap dynamics, light intensity, soil humidity, climate-induced disturbance regimes as well as soil properties and the composition of the regeneration layer all modulate regeneration (Emborg, 1998; Svoboda et al., 2010; Muscolo et al., 2014; Tinya et al., 2019). Furthermore, the impact of deer browsing on tree regeneration is a common and widely discussed problem in many European temperate and boreal forest types (Ammer, 1996; Barančeková et al., 2007).

Besides the above mentioned factors, however, different phases of the regeneration process are reportedly also affected by aboveground and below-ground competition between tree seedlings and plant species of the understorey herbaceous vegetation cover (Davis et al., 1998; Ricard et al., 2003; Booth, 2004; Royo and Carson, 2008; De Lombaerde et al., 2019). De Lombaerde et al. (2019) argue that manipulation of the overstorey cover (also tree layer or canopy cover) to reduce its abundance and shade-casting ability can increase tree seedling competitiveness. However, stress factors during the regeneration phase of seedling establishment are particularly impactful in regard to the renewing of forest ecosystems (Terwei et al., 2013). In managed forests, the regeneration is following a series of anthropogenic disturbances due to silvicultural measures, such as harvesting and soil preparation, in addition to the above mentioned biotic and abiotic factors. During plantation establishment or natural forest regeneration, forest ecosystems may be impacted especially heavily by alien plant invasions due to the increase in light and nutrient availability that intensifies competition for limited sources. Furthermore, understanding the impact mechanisms of alien plant species during the critical stage of forest regeneration has important implications for invasive species management and forest management in general.

\section{Objective and Aim}

This review sets out to analyze the impact of alien plant species on forest regeneration, which we consider to be one of the key stages in tree ecology for the survival of forest ecosystems in the future. The focus of this study is directly relevant to practitioners, forest managers and the conservation management of forests.

With this review, we aim to provide an overview of 48 research studies reporting on the impact and/or management of IAS in European temperate forests. This information has hitherto not been systematically collated and analyzed-a process required to identify research lacunae and delineate the current state of the art. Against this background, we addressed the following research questions: 
1. Which IAS have a negative influence on forest regeneration in Central European forests?

2. The regeneration of which specific tree species in Central European forests is threatened by IAS?

3. Which mechanisms and features of IAS have an impact on regeneration?

4. Which management measures and considerations can be employed to counter the impact of IAS on regeneration?

\section{METHODS}

\section{Ethics Statement}

This paper does not involve field studies or primary data-it is purely an analysis of information in existing peer-reviewed studies (Figure 2).

\section{Study Area}

To address our research questions, we decided to take a closer look at Central Europe, establishing a clear structure by using the terrestrial ecoregions classification according to the WWF (WWF, 2020). The terrestrial ecoregions include 14 major habitat types ranging from the wettest of forest types to the driest and hottest desert conditions. Each of these 14 major habitat types has a wide range of ecoregion categories, which are in turn divided into subtypes. For Europe, this subtype classification is equivalent to the Digital Map of European Ecological Regions (hereinafter DMEER) (Bohn et al., 2003) as shown in Figure 1. The major habitat for Central Europe are the "temperate broadleaf and mixed forests" with their two habitat subtypes "palearctic temperate coniferous forests" and "palearctic temperate broadleaf and mixed forests". The typical characteristic of the "temperate broadleaf and mixed forests" is a forest structure consisting of four layers: The main layer is a canopy with dominant mature species, which is accompanied by a second layer of trees, a shrub layer, and a grass and herb layer. Within the habitat subtype "palearctic temperate coniferous forests", we reviewed studies pertaining to countries belonging to the subdivision "Alps conifer and mixed forests". Within the habitat subtype "palearctic temperate broadleaf and mixed forests", we reviewed studies pertaining to countries belonging to the subdivisions "Dinaric Mountains mixed forests", "Pannonian mixed forests", "Central European mixed forests", and "Western European broadleaf forests". Figure $\mathbf{3}$ provides an overview of the specific countries covered in the reviewed studies.

\section{Search Query and Criteria}

We followed a multi-step protocol to compile the publications for the literature review (Figure 2). Empirical studies fulfilling all of the following criteria were selected for further analysis: 1) published between 1978 and 2019,2) conducted in European temperate forests as defined in Figures $\mathbf{1}$ and $\mathbf{3}$ ) analyzing the direct or indirect impact of alien plant species on regeneration according to the research questions. Reviews, meta-analyzes and book chapters were excluded. In the first step, we focused only on research articles and review articles. The search for publications was performed using the ScienceDirect database (ScienceDirect, 2019). In total, four literature searches were conducted between 7 February and 30 March 2019 using the following search terms:

1. "temperate forest" AND "Europe" AND "invasive plant species" OR "non-native plant species" OR "exotic plant species" $\rightarrow 982$ results

2. "regeneration" AND "forest" AND "Europe" AND "invasive plant species" OR "non-native plant species" OR "exotic plant species" $\rightarrow 956$ results

3. "biological invasion" AND "vegetation" AND "regeneration" AND "forest" $\rightarrow 224$ results

4. "rejuvenation" AND "forest" AND "Europe" AND "invasive plant species" OR "non-native plant species" OR “exotic plant species" $\rightarrow 980$ results

In addition, the following five search queries for specific alien plant species, which are among the most frequently mentioned IAS

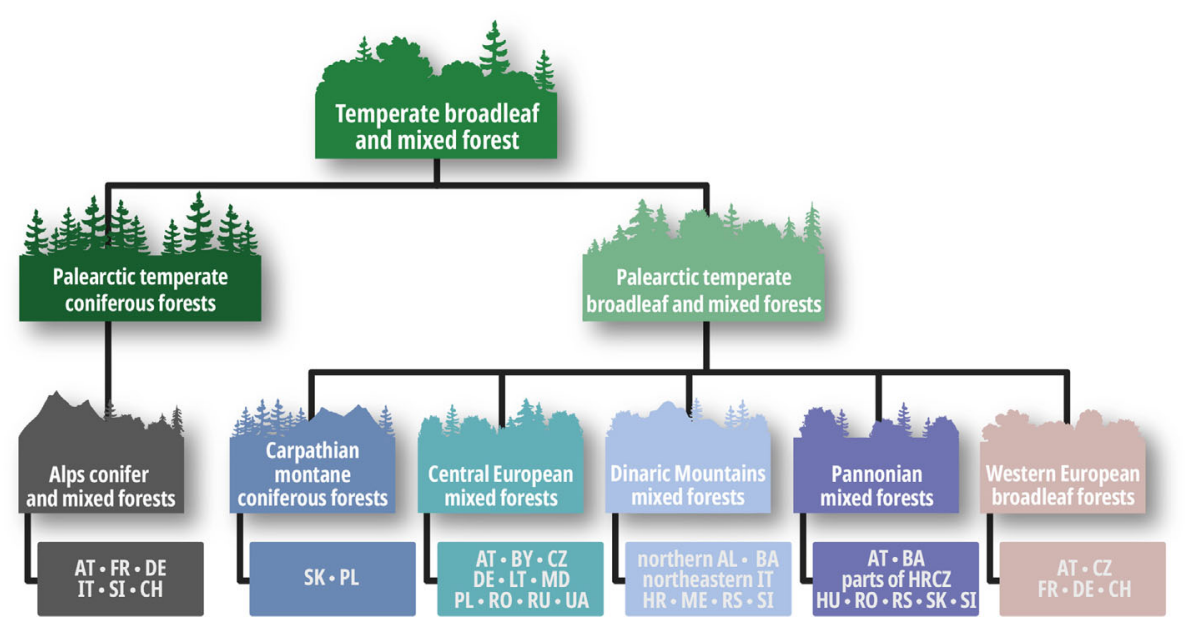

FIGURE 1 | Overview of the ecological regions and countries from the Digital Map of European Ecological Regions appearing in the study. 


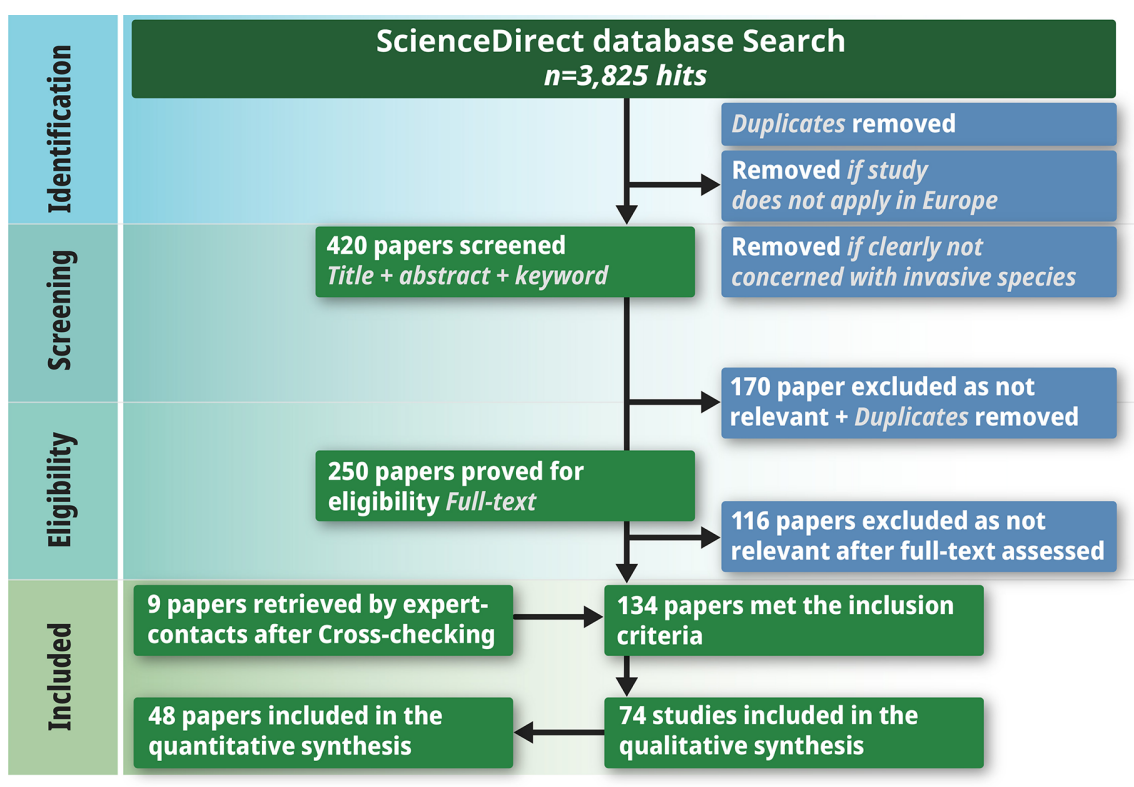

FIGURE 2 | PRISMA diagram outlining the selection procedure for papers on IAS influence on forest regeneration in Central European forests.

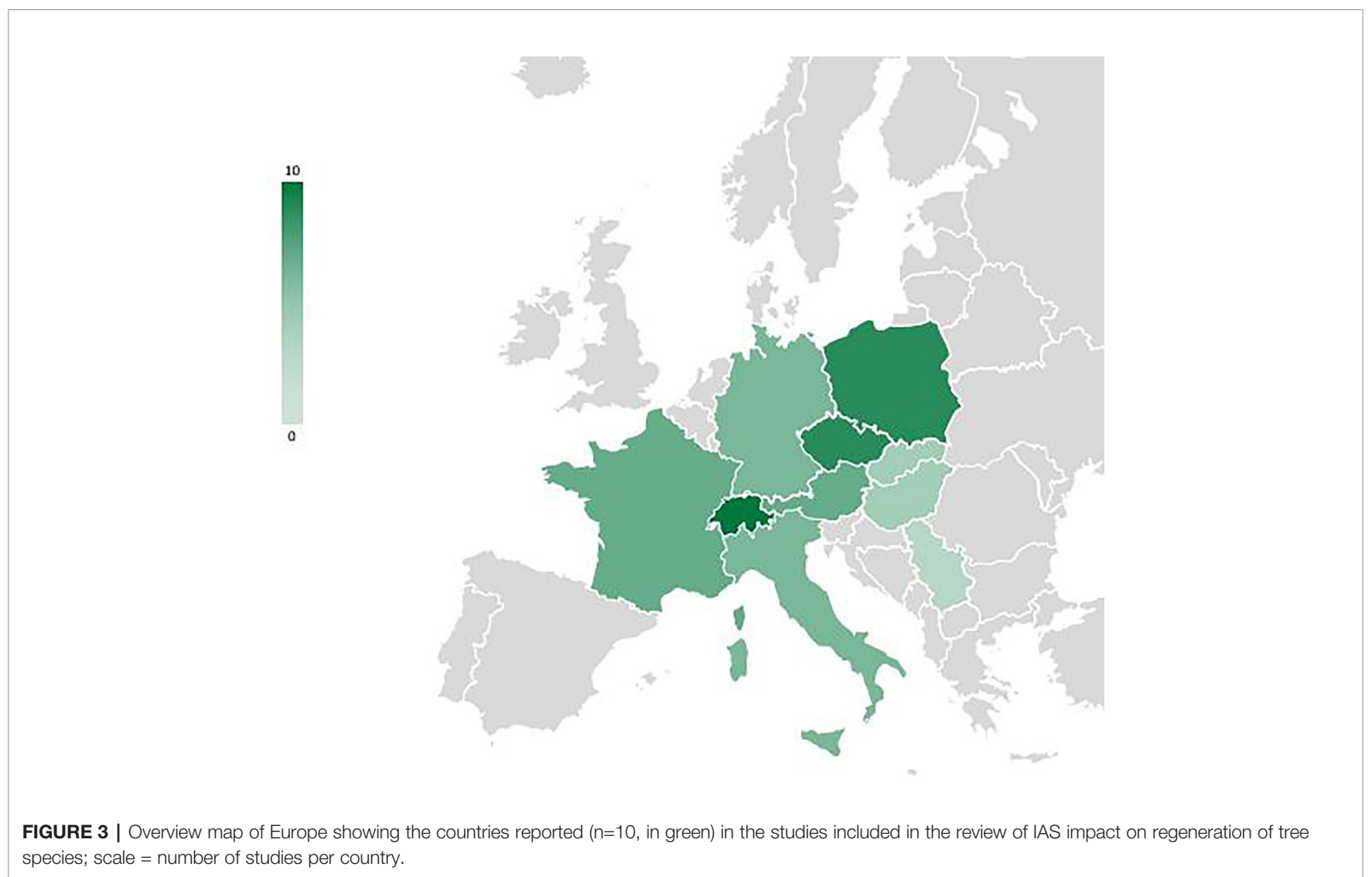


in temperate forests in grey literature, data bases (EPPO, http://gd. eppo.int/; GISD, http://www.iucngisd.org/gisd/; GRIIS, http://griis. org/; 20.02.2019) and local experts were used for cross-checking (Dziub, 2019):

6. "Solidago gigantea" AND "forest" AND "Europe" $\rightarrow 63$ results 7. "Impatiens glandulifera" AND "forest" AND "Europe" $\rightarrow 85$ results 8. "Robinia pseudoacacia" AND "forest" AND "Europe" AND "invasive" $\rightarrow 246$ results

9. "Fallopia" AND "forest" AND "Europe" $\rightarrow 160$ results

10. "Ailanthus altissima" AND "forest" AND "Europe" AND "invasive" $\rightarrow 129$ results

These nine search queries produced a total of 3,825 hits. The first reduction removed all hits that did not apply to the selected research area (Central European forests, as stated in Figure 1) or were not clearly concerned with invasive species and resulted in 420 remaining publications. For this reduction, only the title, abstract and keywords of each study were analyzed.

In the next step, every duplicated publication was removed, which left 250 publications to be examined more closely. The final selection step was to read the abstracts of these 250 papers to obtain an overview of their contents. Completion of this process left a final number of 134 publications. In addition, we contacted IAS researchers known to members of our research group and asked them to provide lists of their publications during the past years (Dziub, 2019). Cross-checking these lists against the papers we already had resulted in a further nine papers for review. In the end, we had 143 publications to read in full in order to determine whether they provided any answers to our research questions. This reading left us with 74 relevant papers, 26 of which were important in terms of background information but did not deal with our specific research questions. We thus ended up with a grand total of 48 papers relevant for answering our meta-study's research questions.

\section{Literature Analysis and Synthesis}

The analysis of impact mechanisms followed the definitions by Blackburn et al. (2014), which are in widespread use for socioeconomic impact classification of alien taxa (Bacher et al., 2018). The impact mechanisms were slightly adapted for the analysis of reported impacts of alien plant species on tree regeneration. A further goal of this review was to synthesize the management recommendations reported in empirical studies. We collated the technical information and classified it according to IAS management categories, which follow the definitions of the EU Regulation on IAS (EU Regulation, 2014) (Table 3): "Early detection", "Adaptation of silvicultural measures", "Eradication measures", and "no management". The applied taxonomy follows the Plant List (The Plant List, 2013, www.theplantlist.org). Microsoft Excel 2010 was used for data management and data control, and $\mathrm{R}$ version 3.4.2 (R Core Team, 2017) was used for processing the data analysis.

\section{RESULTS}

Of the 48 analyzed publications, most studies constitute descriptive empirical research focused on individual forest sites $(71 \%, n=34)$ or a comparison between two or more forest sites $(23 \%, n=11)$. Only one study is an experimental study. Four percent $(n=2)$ of the studies do not focus on IAS in forests specifically, but instead on various different land use types (Annex 1).

Nineteen percent of the studies are related to unspecified forests at the country level (Alps conifer and mixed forests; Central European mixed forests; Dinaric Mountains mixed forests; Pannonian mixed forests; Western European broadleaf forests), and a further 19\% deal specifically with Central European mixed forests or Alps conifer and mixed forests. 25\% are specifically on Western European broadleaf forests. Pannonian mixed forests are represented in $15 \%$ of the studies, while Carpathian montane coniferous forests appear in only $4 \%$. Studies from Switzerland, Poland and the Czech Republic predominate (Figure 4).

The studies are not distributed equally across the study area. Also, out of the entire 41 years considered (1978-2019), only publications from 14 different years within the period from 1994 to 2018 met the criteria for further analysis, and nearly $80 \%$ of those studies were published during the past decade (Table 1).

In total, 53 alien plant species were targeted by research. The focus of 17 of the relevant studies (35\%) lies on providing a list of alien plant species and their effects on forest ecosystems, while 31 studies $(65 \%)$ analyze or test the impact of specific selected species. Only $28 \%(n=17)$ of the studies do not describe at least one impact mechanism of alien plant species on regeneration (Table 2). Competition is the most frequently reported impact mechanism (34\%, $\mathrm{n}=21$ ), observed for 30 alien plant species. The alien plant species Robinia pseudoacacia L. (9.7\%, n=14), Prunus serotina Ehrh. (8.3\%, $\mathrm{n}=12)$, Ailanthus altissima (Mill.) Swingle (6.9\%, $\mathrm{n}=10)$, Impatiens glandulifera Royle (4.9\%, $\mathrm{n}=7)$, Acer negundo L. (4.9\%, $\mathrm{n}=7)$, Solidago canadensis L. $(4.9 \%, \mathrm{n}=7)$, and Impatiens parviflora DC. $(4.2 \%, \mathrm{n}=6)$ are the most frequently studied species with an impact on forest regeneration in the analyzed publications. In total, 21 tree species are reported to be impacted by IAS in 24 studies. The species whose regeneration is most often reported to be influenced are the temperate tree species Quercus robur $(\mathrm{n}=7)$, Fagus sylvatica $(\mathrm{n}=5)$, and Carpinus betulus $(\mathrm{n}=4)$ (Figure 5).

More than half of the studies $(54 \%, \mathrm{n}=26)$ do not recommend specific management measures for regeneration. In $18 \%$ of the studies, adaptation of silvicultural measures is discussed in a species-specific fashion, and $21 \%$ of the publications recommend eradication measures for a total of 11 alien plant species. None of the studies specifically recommend not managing alien plants at all (Table 3).

\section{SYNTHESIS}

\section{IAS With a Negative Influence on Forest Regeneration of Native Tree Species}

The detected 53 invasive alien plant species negatively influencing forest regeneration of 21 native tree species, include mostly woody alien tree and shrub species, followed by perennial alien plant species (Annex 1). For most native tree species, the link to the influencing IAS relayed on one or two study only. The highest number of studies was found for the forests regeneration of 


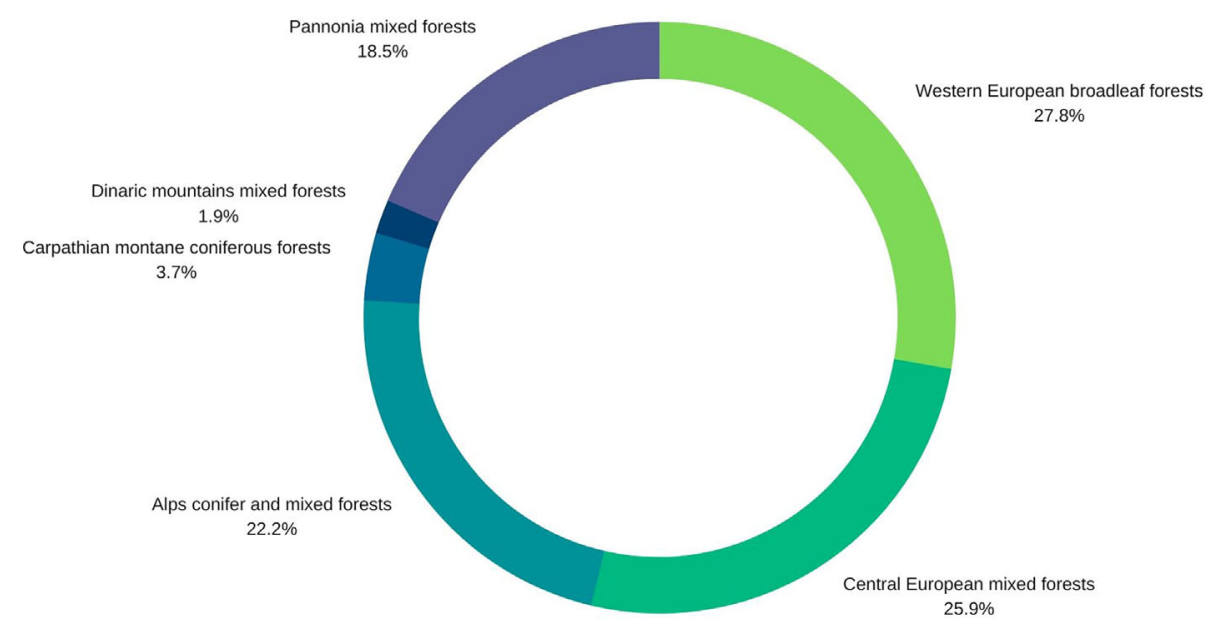

FIGURE 4 | Pie diagram of forest type representation in the 48 papers selected for the quantitative synthesis.

pedunculate oak (Quercus robur), which was reported to be negatively influenced of the most number of IAS, such as Prunus serotina, Solidago canadensis, Solidago gigantea, Quercus rubra, Impatiens parviflora, Robinia pseudoacacia, and Reynoutria sp. (Closset-Kopp et al., 2007; Sebert-Cuvillier et al., 2007; Nováková, 2008; Petrášová et al., 2013; Terwei et al., 2013; Schiffleithner and Essl, 2016; Florianová and Münzbergová, 2017). Similar IAS, are affecting the regeneration of the sessile oak (Quercus petraea) and the common hornbeam (Carpinus betulus) (Sebert-Cuvillier et al., 2007; Radtke et al., 2013; Schiffleithner and Essl, 2016). The regeneration of Scots pine (Pinus sylvestris) was negatively influenced by Prunus serotina and Robinia pseudoacacia (SebertCuvillier et al., 2007; Rahmonov, 2009).

\section{Impact Mechanisms Competition for Resources}

Competition-defined as the process of alien plants competing with native tree species for resources-is the most commonly reported impact mechanism of alien plant species on the regeneration of tree species. According to the literature analysis, competition for light has the greatest impact on tree seedling establishment (Radtke et al., 2013; Terwei et al., 2013). Light availability is often expressed in terms of canopy cover and the invasion by light-demanding species is likened to management-related disturbances that lead to changes in light availability (Schnitzler, 1994; Terwei et al., 2013; Vacchiano et al., 2016). Under low light availability circumstances, competition for light becomes crucial for the successful establishment of tree seedlings (Closset-Kopp et al., 2007). Terwein et al. (2013) showed that the abundance of Carpinus betulus seedlings depends on low herb layer cover, which indicates less competition for light. The canopy gap ecology in relation to competition for light becomes particularly critical in regard to the alien plant species Prunus serotina (Closset-Kopp et al., 2007; Sebert-Cuvillier et al., 2007; Terwei et al., 2013; Dyderski et al., 2015; Dreiss et al., 2016). Competition for light of the IAS Sodiago gigantea, Impatiens glandulifera and Conzya canadensis, was in particular observed in nutrient-rich forests and frequently disturbed sites, such as the riparian mixed oak-elm-ash hardwood forests along great rivers (Fraxino-Ulmetum and Ulmeto-Quercetum) (Petrášová et al., 2013).

Competition mechanisms also include resistance to drought events. Knüsel et al. (2015), for example, showed that Ailanthus altissima successfully competes with the tree species Castanea sativa due to its drought resistance, which $A$. altissima maintains throughout all regeneration phases.

\section{Chemical Impact on Regeneration}

Chemical impact on regeneration refers to changes caused by the alien plant to the chemical biotope characteristics of the native environment, nutrient and/or water cycles, disturbance regimes or natural succession. The indirect chemical impact of legume plant species, which have the ability to fix nitrogen from the air, leads to structural ecosystem changes and the creation of new plant communities and therefore negatively affects the forest regeneration.

Few among the examined studies deal with the release of allelochemicals, which impact the regeneration of neighboring tree seedlings directly (Schnitzler, 1994; Rahmonov, 2009; Rusterholz et al., 2018). Chemical impacts also include the ability of alien plants to alter chemical and biochemical soil properties, which in turn can cause changes in the native species richness above and below the ground (Rusterholz et al., 2018). Gaggini et al. (2018) found that the alien species Impatiens glandulifera changes the soil fungal and bacterial communities in conifer and mixed forests by releasing naphthoquinones. Another aspect of chemical impacts is the fact that the chemical composition of plant litter from alien plants such as Robinia pseudoacacia can cause high levels of nitrogen in the upper soil horizons, thereby exerting an effect on regeneration (Rahmonov, 2009).

\section{Physical Impact on Regeneration}

Physical impact on regeneration refers to changes to the physical biotope characteristics of the native environment, nutrient and/or 
TABLE 1 | Selected and analyzed studies included in the quantitative synthesis of this meta-study ( $n=48$ papers), showing the number of IAS analyzed in the paper and the country of the research study.

\begin{tabular}{|c|c|c|c|}
\hline Year & Year and publication & No.of IAS studied & Countries \\
\hline 1994 & Schnitzler, 1994 & 1 & FR; GE \\
\hline 1995 & Pyšek and Prach (1995) & 1 & $\mathrm{CZ}$ \\
\hline \multirow[t]{2}{*}{2005} & Grund et al. (2005) & 2 & $\mathrm{CH}$ \\
\hline & Moravcová et al. (2005) & 1 & $\mathrm{CZ}$ \\
\hline \multirow[t]{3}{*}{2007} & Chmura and Sierka, 2007 & 1 & $P L$ \\
\hline & Closset-Kopp et al., 2007 & 1 & FR \\
\hline & Sebert-Cuvillier et al., 2007 & 1 & FR \\
\hline 2008 & Nováková, 2008 & 12 & $\mathrm{CZ}$ \\
\hline 2009 & Rahmonov, 2009 & 1 & $\mathrm{PL}$ \\
\hline \multirow[t]{4}{*}{2011} & Ammer et al., 2011 & 1 & GE \\
\hline & Essl et al., 2011 & na & AT \\
\hline & Motard et al., 2011 & 1 & $\mathrm{FR}$ \\
\hline & Pyšek et al. (2011) & na & $\mathrm{CZ}$ \\
\hline \multirow[t]{2}{*}{2012} & Ferréa et al. (2012) & 2 & $\mathrm{IT}$ \\
\hline & Maringer et al., 2012 & 15 & $\mathrm{CH}$ \\
\hline \multirow[t]{4}{*}{2013} & Petrášová et al., 2013 & 15 & HU; SK \\
\hline & Radtke et al., 2013 & 2 & IT \\
\hline & Schmiedel and Tackenberg (2013) & 1 & GE \\
\hline & Terwei et al., 2013 & 2 & $\mathrm{IT}$ \\
\hline \multirow[t]{7}{*}{2014} & Halarewicz and Zołnierz, 2014 & 1 & $\mathrm{PL}$ \\
\hline & Höfle et al. (2014) & 3 & AT \\
\hline & Kopeć et al., 2014 & na & $\mathrm{PL}$ \\
\hline & Rouifed et al. (2014) & 1 & FR \\
\hline & Ruckli et al., 2014 & 1 & $\mathrm{CH}$ \\
\hline & Rusterholz et al., 2014 & 1 & $\mathrm{CH}$ \\
\hline & Staska et al., 2014 & 1 & AT \\
\hline \multirow[t]{3}{*}{2015} & Dyderski et al., 2015 & 12 & $P L$ \\
\hline & Knüsel et al., 2015 & 1 & $\mathrm{CH}$ \\
\hline & Laube et al., 2015 & 2 & GE \\
\hline \multirow[t]{7}{*}{2016} & Berg et al. (2016) & 10 & AT \\
\hline & Braun et al. (2016) & 31 & Central Europe \\
\hline & Nobis et al., 2016 & na & PL \\
\hline & Pěknicová et al. (2016) & 3 & $\mathrm{CZ}$ \\
\hline & Schiffleithner and Essl, 2016 & 3 & AT; CZ \\
\hline & Seipel et al. (2016) & 2 & $\mathrm{CH}$ \\
\hline & Vacchiano et al., 2016 & na & $\mathrm{IT}$ \\
\hline \multirow[t]{6}{*}{2017} & Chudomelová et al., 2017 & na & $\mathrm{CZ}$ \\
\hline & Florianová and Münzbergová, 2017 & 1 & $\mathrm{CZ}$ \\
\hline & Gaggini et al. (2017) & na & $\mathrm{CH}$ \\
\hline & Nobis et al., 2017 & na & PL \\
\hline & Radovanović et al., 2017 & 1 & RS \\
\hline & Rusterholz et al., 2017 & 1 & $\mathrm{CH}$ \\
\hline \multirow[t]{6}{*}{2018} & Campagnaro et al., 2018 & 5 & Central Europe \\
\hline & Erdős et al. (2018) & na & $H U$ \\
\hline & Gaggini et al., 2018 & 1 & $\mathrm{CH}$ \\
\hline & Łapok et al. (2018) & 12 & $\mathrm{PL}$ \\
\hline & Rusterholz et al., 2018 & 1 & $\mathrm{CH}$ \\
\hline & Thurm et al. (2018) & na & Europe \\
\hline
\end{tabular}

The studies were published in between the year 1994 and 2018 (na, no species-specific information stated).

water cycles, disturbance regimes, or natural succession. Changes in soil humidity due to invasion by alien plants are among the main effects in this category. This impact is described, for example, for the alien shrubs Prunus laurocerasus (Rusterholz et al., 2018) and Prunus serotina (Terwei et al., 2013). The physical impact observed of $P$. serotina and Ailanthus altissima on co-occuring tree species in temperate forests is linked to the demographic process through which individuals decrease in size and delay mortality (Closset-Kopp et al., 2007; Knüsel et al., 2015).

\section{Structural Impact on Regeneration}

Structural impact on regeneration refers to alien plants causing changes in the structural biotope characteristics of the native environment, nutrient and/or water cycles, disturbance regimes, or natural succession. At species level the structural impact was observed for the IAS Prunus serotina, Robinia pseudoacacia and Ailathus altissima (Rahmonov, 2009; Campagnaro et al., 2018). This impact mechanism is mainly discussed as the indirect ability of individual plant invaders to serve as indicators for changes in forest habitat structures and functions as well as regeneration (Campagnaro et al., 2018). Structural impacts on regeneration include the homogenization of species composition in the herb layer, changes to the seed bank, effects on species diversity and changes in the forest structure due to ruderalization (Rahmonov, 2009; Halarewicz and Zołnierz, 2014; Staska et al., 2014; Nobis et al., 2016; Campagnaro et al., 2018). The effects of structural changes to forest ecosystems are time-dependent. For example, structural changes caused by the invasion of a deciduous forest by Impatiens glandulifera are documented as becoming visible 5 years after the invasion and causing significant alterations after 13 years (Rusterholz et al., 2017). Oak forests and riparian forests in particular are reported as being affected by the impact mechanism of structural changes caused by alien plants (Kopeć et al., 2014; Nobis et al., 2016; Chudomelová et al., 2017; Nobis et al., 2017; Radovanović et al., 2017).

\section{Indirect Impacts Through Interaction With Other Species}

This mechanism refers to alien plants interacting with other native or alien taxa (e.g. through any mechanism including pollination, seed dispersal, apparent competition and mesopredator release). Such indirect impacts have been found e.g. for Impatiens glandulifera in regard to the arbuscular mycorrhiza symbiosis with a negative impact on the regeneration of Acer pseudoplatanus (Ruckli et al., 2014). Furthermore, microarthropod species richness can be affected by I. glandulifera invasion in terms of changes to the nutrient cycle, which may indirectly impact regeneration (Rusterholz et al., 2014). Apparent indirect competition however was observed for Amorpha fructicosa in poplar and willow habitat and for Ailanthus altissima and Robinia pseudoacacia in conifer and mixed forests (Radtke et al., 2013; Radovanović et al., 2017). However, detailed studies analyzing the complexity of the indirect impact mechanisms of IAS in ecological network of European forest ecosystems are rare.

\section{Other Impact Mechanisms}

Hybridization of alien plant species with native tree species as well as the impact mechanisms of disease transmission from alien plant species to native tree species and parasitism of native tree species by alien taxa, which can cause direct or indirect deleterious effects on native tree species, are not relevant for the regeneration of tree species. These impact mechanisms were not described in the 48 analyzed papers.

\section{Combined Impact Mechanisms}

Most alien plant species seem to exhibit a combination of impact mechanisms affecting the regeneration of native plant species (Table 2). Especially, many tree species, such as Acer negundo, Ailanthus altissima, Prunus laurocerasus, Prunus serotina, and Robinia 
TABLE 2 | Impact mechanisms (Competition for resources, Chemical impact on regeneration, Physical impact on regeneration, Structural impact on regeneration, and Indirect impacts through interaction with other species) exhibited by the IAS listed in the studies, showing the number of studies and the number of IAS for early detection, adaptation of silvicultural measures, and eradication measures.

\begin{tabular}{|c|c|c|c|c|c|}
\hline & Competition & Chemical & Physical & Structural & Indirect \\
\hline No. of studies & 30 & 4 & 2 & 5 & 8 \\
\hline Acer negundo $L$. & $\checkmark$ & $\checkmark$ & - & $\checkmark$ & $\checkmark$ \\
\hline Aesculus hippocastanum L. & - & - & - & - & - \\
\hline Ailanthus altissima (Mill.) Swingle & $\checkmark$ & - & $\checkmark$ & $\checkmark$ & $\checkmark$ \\
\hline Ambrosia artemisifolia L. & $\checkmark$ & - & - & - & - \\
\hline Amorpha fruticosa $L$. & - & - & - & - & $\checkmark$ \\
\hline Bidens frondosa $L$. & $\checkmark$ & - & - & - & - \\
\hline Buddleja davidii Franch. & $\checkmark$ & - & - & - & - \\
\hline Catalpa bignonioides Walter & - & - & - & - & - \\
\hline Celtis orientalis $L$. & $\checkmark$ & - & - & - & - \\
\hline Cinnamomum camphora (L.) J. Pres/ & $\checkmark$ & - & - & - & - \\
\hline Conzya canadensis (L.) Cronquist & $\checkmark$ & - & - & - & - \\
\hline Diospyros lotus L. & $\checkmark$ & - & - & - & - \\
\hline Erigeron annuus (L.) Desf. & $\checkmark$ & - & - & - & - \\
\hline Fraxinus pennsylvanica Marshall & $\checkmark$ & - & - & - & - \\
\hline Galeobdolon argenatum (L.) L. & $\checkmark$ & - & - & - & - \\
\hline Impatiens glandulifera Royle & $\checkmark$ & $\checkmark$ & - & $\checkmark$ & $\checkmark$ \\
\hline Impatiens parviflora DC. & $\checkmark$ & - & - & - & - \\
\hline Phytolacca americana L. & $\checkmark$ & - & - & - & - \\
\hline Prunus laurocerasus L. & $\checkmark$ & - & - & $\checkmark$ & $\checkmark$ \\
\hline Prunus serotina Ehrh. & $\checkmark$ & $\checkmark$ & $\checkmark$ & $\checkmark$ & $\checkmark$ \\
\hline Quercus rubra L. & $\checkmark$ & - & - & $\checkmark$ & $\checkmark$ \\
\hline Reynoutria japinica (Houtt.) Ronse Decr. & $\checkmark$ & - & - & - & - \\
\hline Reynoutria ssp. & $\checkmark$ & - & - & - & - \\
\hline Robinia pseudoacacia L. & $\checkmark$ & $\checkmark$ & - & $\checkmark$ & $\checkmark$ \\
\hline Solanum chenopodioides Lam. & $\checkmark$ & - & - & - & - \\
\hline Solidago canadensis L. & $\checkmark$ & $\checkmark$ & - & - & - \\
\hline Solidago gigantea L. & $\checkmark$ & - & - & - & - \\
\hline Symphyotrichum lanceolatum Willd. & $\checkmark$ & - & - & - & - \\
\hline Symphyotrichum novi-belgii (L.) & $\checkmark$ & - & - & - & - \\
\hline \multicolumn{6}{|l|}{ G.L.Nesom } \\
\hline Trachycarpus fortunei (Hook.) H.Wendl. & $\checkmark$ & - & - & - & - \\
\hline Vitis vulpina $L$ & $\checkmark$ & - & - & - & - \\
\hline
\end{tabular}

pseudoacacia have reportedly several mechanisms to impact forest regeration. Robinia pseudoacacia originating from North America is a good example of an invading plant species that uses different impact mechanisms at different stages of invasion. It increases nitrogen availability, changes light conditions, creates plant communities and is also associated with allopathic activity (Rahmonov, 2009; Campagnaro et al., 2018). R. pseudoacacia can be a desirable and beneficial species for forest management on degraded, sandy, urban, and initial soil, while other studies report its negative impacts on riparian forests, Pannonian mixed forests and Western European broadleaf forests. Its effects particularly affect the natural regeneration of Ulmus laevis, Ulmus minor, Quercus pubescens, Quercus petrea, Quercus robur, Populus sp., Crataegus monogyna, Betula pendula, Pinus sylvestris, and Fraxinus angustifolia (Rahmonov, 2009; Maringer et al., 2012; Petrášová et al., 2013; Radtke et al., 2013; Terwei et al., 2013).

\section{Management Recommendations Early Detection}

Measures for early detection include forest maintenance and restoration (Terwei et al., 2013; Nobis et al., 2017) as well as raising the awareness of forest managers and owners for biological invasions (Motard et al., 2011). Early detection of plant invasion is particularly essential for unmanaged sites, forests at low elevations (Laube et al., 2015) and urban forests (Sjöman et al., 2016). Additionally, it is important to adequately inform citizens about the environmental impact of IAS (Kowarik, 2010; Rupp et al., 2017).

\section{Adaptation of Silvicultural Measures}

Recommendations concerning the adaptation of silvicultural measures include preventive actions such as the recommendation to plant more native tree species. Furthermore, continuous tree cover and longer rotation periods are recommended where appropriate to promote shadier conditions. The slight thinning of forest areas should be avoided to reduce the risk of management disturbances that may function as pathways for the introduction of alien plant species into the forest. Finally, alternative cutting regimes to simple clearcutting, such as selection or shelterwood systems applied in close-to-nature silviculture, should be preferred (Sitzia et al., 2016). When opening dark forest stands that can be colonized by Phytolacca americana, it is recommended to open them quickly and intensively and to begin the regular care in time. Neighbouring stands should not be opened. (Rupp et al., 2017). 


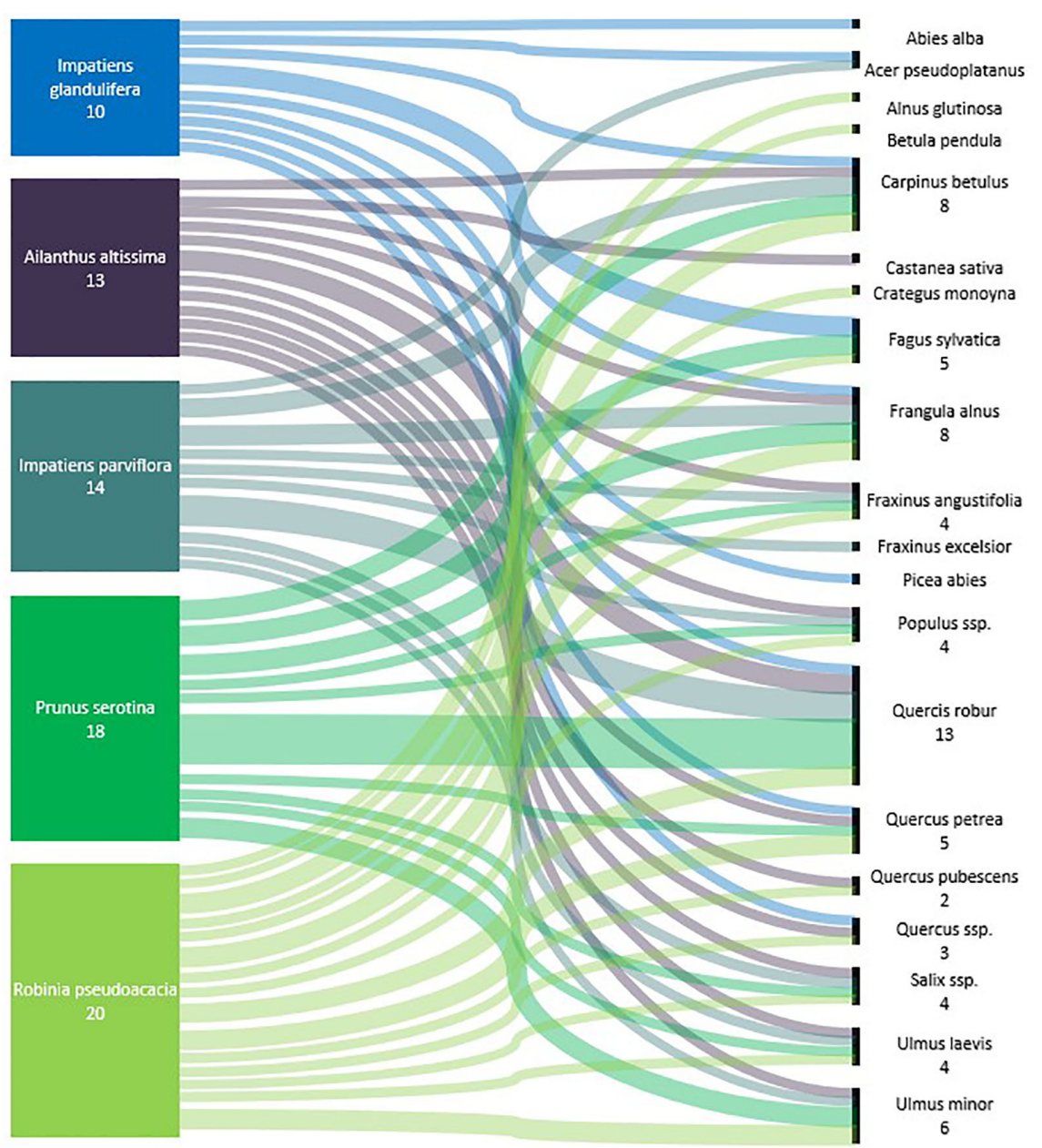

FIGURE 5 | Sankey flow diagram showing the link between the five most frequent IAS with a negative influence on forest regeneration of native tree species in Central European forests ( $\mathrm{n}=$ number of studies reporting a direct or indirect influence).

\section{Eradication Measures}

Once alien plants are established, a set of technical measures to control them and ensure the regeneration success of native species are recommended. The eradication measures recommended for alien plant species affecting the regeneration of native tree species include the following tasks: biological control, mowing, hand pulling, manual removal, felling, chemical control, grazing, girdling, and general management of the area.

Less concrete measures for individual IAS were also found in the studied literature. Ammer et al. (2011) launched one of the few experiments to observe how Impatiens glandulifera affects the natural rejuvenation of birch and the artificial regeration of spruce and fir. They were able to prove statistically that $I$. glandulifera does not limit the growth of rejuvenation; only isolated losses of fir trees could be determined. This is due to the different growth rhythms of I. glandulifera and the examined tree species. The height growth of the native trees begins much earlier than that of the annual I. glandulifera, which seems to decouple the competition for resources. The study did not investigate whether the sprouting of trees is affected by $I$. glandulifera (Ammer et al., 2011).

When looking through articles from non-scientific journals, we also found some specific management measures, especially eradication measures. An experiment was performed in BadenWürttemberg, Germany in which Phytolacca americana was impregnated in order to prevent its natural rejuvenation sprouting. In order to be able to contain $P$. americana with an economical use of labour and costs, measures must be taken before seed banks are established. The most successful measure was the digging up of the entire plant prior to seed collection (Rupp et al., 2017).

\section{DISCUSSION}

\section{Review and Synthesis of the Literature}

This synthesis is based exclusively on the results of 48 empirical studies conducted in European temperate forests, and its general applicability should therefore be tested in future research. 
TABLE 3 | List of IAS with recommended management measures in the studies, showing the number of studies and the number of IAS for early detection, adaptation of silvicultural measures and eradication measures.

\begin{tabular}{|c|c|c|c|}
\hline & $\begin{array}{c}\text { Early } \\
\text { detection }\end{array}$ & $\begin{array}{c}\text { Adaptation of } \\
\text { silvicultural } \\
\text { measures }\end{array}$ & $\begin{array}{c}\text { Eradication } \\
\text { measures }\end{array}$ \\
\hline No. of studies & 6 & 11 & 10 \\
\hline Acer negundo $L$. & - & - & $\checkmark$ \\
\hline Aesculus hippocastanum L. & - & - & $\checkmark$ \\
\hline Ailanthus altissima (Mill.) Swingle & $\checkmark$ & - & $\checkmark$ \\
\hline Bidens bipinnata L. 1753 & - & $\checkmark$ & - \\
\hline Buddleja davidii Franch. & - & $\checkmark$ & - \\
\hline $\begin{array}{l}\text { Cinnamomum camphora (L.) J. } \\
\text { Presl }\end{array}$ & - & $\checkmark$ & - \\
\hline Conzya canadensis (L.) Cronquist & - & $\checkmark$ & - \\
\hline Diospyros lotus L. & - & $\checkmark$ & - \\
\hline $\begin{array}{l}\text { Heracleum mantegazzianum } \\
\text { Sommier \& Levier }\end{array}$ & - & - & $\checkmark$ \\
\hline Impatiens glandulifera Royle & $\checkmark$ & $\checkmark$ & $\checkmark$ \\
\hline Impatiens parviflora DC. & $\checkmark$ & $\checkmark$ & $\checkmark$ \\
\hline Ligustrum sinense Lour. & - & $\checkmark$ & - \\
\hline Lonicera japonica Thunb. & - & $\checkmark$ & - \\
\hline $\begin{array}{l}\text { Paulownia tomentosa (Thunb.) } \\
\text { Steud. }\end{array}$ & - & $\checkmark$ & - \\
\hline Phytolacca americana L. & - & $\checkmark$ & - \\
\hline Prunus laurocerasus L. & - & $\checkmark$ & - \\
\hline Prunus serotina Ehrh. & $\checkmark$ & - & $\checkmark$ \\
\hline Quercus rubra $L$. & - & $\checkmark$ & $\checkmark$ \\
\hline $\begin{array}{l}\text { Reynoutria ×bohemica (Chrtek \& } \\
\text { Chrtková) J.P.Bailey }\end{array}$ & - & $\checkmark$ & $\checkmark$ \\
\hline $\begin{array}{l}\text { Reynoutria japinica (Houtt.) Ronse } \\
\text { Decr. }\end{array}$ & - & $\checkmark$ & - \\
\hline $\begin{array}{l}\text { Reynoutria sachalinensis } \\
\text { (F.Schmidt ex Maxim.) Nakai }\end{array}$ & - & $\checkmark$ & - \\
\hline Reynoutria ssp. & - & $\checkmark$ & $\checkmark$ \\
\hline Robinia pseudoacacia L. & - & $\checkmark$ & $\checkmark$ \\
\hline Solanum chenopodioides Lam. & - & $\checkmark$ & - \\
\hline $\begin{array}{l}\text { Trachycarpus fortunei (Hook.) } \\
\text { H.Wendl. }\end{array}$ & - & $\checkmark$ & - \\
\hline
\end{tabular}

Furthermore, forest management was not included in the search queries, and the synthesis of IAS management approaches and measures consist mostly of expert recommendations that have not been tested in field trials and experiments. Nevertheless, we offer a classification reflecting the approaches taken in IAS management over the past three decades. More detailed information may be included in technical reports in various local languages that were not analyzed within this meta-study.

\section{The Impact of IAS on Regeneration in Temperate Forests}

Temperate forests are not resistant to invasion by alien plant species, which can have a negative influence on the forest regeneration of native tree species. The systematic review of 48 studies determined 53 vascular plant species having a negative influence on forest regeneration. The effect however was not reported evenly for all forest types in Central Europe (Figure 4). Riparian forests for instance accounted for the largest portion of studies within our review (25\% of all studies) as well as for the highest numbers of IAS. This is in line with Medvecká et al. (2018) who also report the highest percentage of non-native species in riparian forests and highlight that IAS are well-adapted to riparian forests. Their success may be reasoned by occurrence of frequent disturbances and nutrient enrichment due to periodic flooding events in riparian forests (e.g. Kalusová et al., 2013; Medvecká et al., 2018). Natural or anthropogenic disturbances and forest fragmentation favor the spread of IAS in forest ecosystems, by increasing light and nutrient availability (Brothers and Spingarn, 1992; Alston and Richardson, 2006; Raghubanshi and Tripathi, 2009; GonzálezMoreno et al., 2013). However, Martin et al. (2009) determined that anthropogenic rather than natural disturbances drive the rate of invasion.

Such disturbances together with human-induced propagule input support invasions especially along roadsides, railways (Becker et al., 2005) or urban areas (Sjöman et al., 2016) and make them the highly invaded sites even in unfavored landscapes (Kalusová et al., 2013). According to the study by Kalusová et al. (2013), 47 different IAS species are documented in disturbed European forest and woodlands. Alien plant species are capable of altering species composition and species richness of the ground vegetation. Understanding the processes affecting invasion dynamics is crucial for promoting the successful regeneration of native tree species. The complexity of alien plant invasion processes in temperate forests is driven by the invasibility after disturbances of the individual forest ecosystem and the species-specific characteristics of the involved native and non-native species. Most studied species exhibit particular traits that are linked to habitatindependent invaders of disturbed and nutrient-rich areas, such as large seed numbers, anemochore seed dispersal, light demand, and rapid growth rates (Dreiss and Volin, 2013; Schmiedel et al., 2013; Medvecká et al., 2018). Relatively few alien plant species with long life spans and slow growth rates that can form a persistent seed bank and have life histories similar to those of native plant species have been studied. The primary focus of the research examined for our synthesis lies on alien plants that rapidly invade canopy gaps rather than on "slower" invaders of closed canopy forests that might compete with native tree species in their later life stages. ClossetKopp et al. (2007) conclude that the invasion success of alien plant species, e.g. of Prunus serotina, in closed canopy forests is supported by the ability of those IAS to follow a "sit and wait strategy". Accordingly, alien species following this strategy can invest quickly into growth and reproduction at a favorable moment after a long time waiting for a suitable canopy gap to open up. The "sit and wait" strategy may also support the success of other invasive alien tree and shrub species such as Ailanthus altissima, Acer platanoides, Robinia pseudoacacia and Quercus rubra in Europe, Asia and North America (Knapp and Canham, 2000; Sanford et al., 2003; Lee et al., 2004). According to Ewald (2009), no annual IAS apart from Impatiens spp. has the potential to establish itself in closed forests due to its shadow tolerance. We conclude that processes affecting the invasion of temperate forests with closed canopies are as yet poorly understood and should be studied in more detail given the changing forest management practices. The recent trend toward continuous cover forestry of temperate forests in Europe supports increased canopy closure (Vera, 2000; Schultze et al., 2014; Kirby and Watkins, 2015), which may require further knowledge on its ecological effects such as biological invasibility. 


\section{Implementation in Forest Management}

Invasive alien plants represent an increasingly noticeable problem in the context of the regeneration of native tree species. Various potential management measures to be applied at different stages of biological invasions were identified in our synthesis of 48 studies. The implementation of early detection tools by forest managers and forest owners as well as by the general public can help to identify the spread of alien plants at an early stage as well as supporting the establishment of an early warning system (Kutnar and Pisek, 2013; Sitzia et al., 2016). In particular, species that are recognized invasive in other countries or outside Europe should be treated with caution and prevented where possible (Rejmánek, 2014).

In connection with IAS, management measures in forests are indispensable (Medvecká et al., 2018). Previous studies have shown that a deeper understanding of the driving factors for forest regeneration is needed to assess the impact of IAS in silvicultural scenarios and to improve the silvicultural planning (Montoro Girona et al., 2017; Montoro Girona et al., 2019). Worldwide novel approaches for silvicultural treatments in alternative to clear-cutting have been recently investigated in response to sustainable forest management (Montoro Girona et al., 2016). An adapted management of canopy cover and tree density can be applied to regulate inter-species competition and locally reduce unfavored IAS while promoting native species (Sitzia et al., 2016). Therefore, partial cutting regimes such as shelterwood, selective cutting or seed-tree treatments seem to ensure regeneration and limit the risk of competition with IAS (Montoro Girona et al., 2018).

Furthermore, it is important that a rethinking of forest management takes place. Many IAS would actually have no chance to establish themselves in forests due to their plant sociological characteristics (Abts, 2004) and the implementation of appropriate silvicultural systems would prevent their spread (Sitzia et al., 2016). That they are able to take hold and spread anyway is frequently owed to the destruction of natural biotopes and the disturbance of natural ecosystem dynamics offering a plantsociological advantage to the IAS (Abts, 2004; Martin et al., 2009; Kowarik, 2010). In forests, forest roads and wood storage areas in particular represent potential settlement areas for IAS (Becker et al., 2005; Haseke and Remschak, 2010).

\section{CONCLUSION AND FUTURE RESEARCH}

Alien plant invasions impact forest regeneration directly and indirectly. The 48 studies included in our synthesis discuss a total of 53 invasive alien plant species existing in European temperate forests. We identified five impact mechanisms through which alien plant species affect the regeneration success of native tree species: competition, chemical impacts, physical impacts, structural impacts, and indirect impacts through interaction with other species. Among these impact mechanisms, competition is by far the best-analyzed. Our synthesis shows that physical and chemical impacts as well as changes in soil properties can have significant effects on native species composition and thus on natural regeneration. Further species-specific studies would be very useful in this context to attain a better understanding of ecosystem processes, but also of the influence of forest management purposes. In general, more research is needed to achieve a better understanding of the effects of forest management measures.

Almost no information on the actual effectiveness of management measures is provided in the studies, and we therefore conclude that science and practical forest management need to be linked better and more closely. Long-term experiments developed together with forest managers and owners may help to improve the translation of research results into practice. The review results also show that we lack species-specific experiment designs to investigate the effects of impact mechanisms or management measures in detail.

Knowledge on the possible impacts of alien species is crucial for decision-making processes. For example, forest managers may ask whether natural regeneration is less likely to succeed without further investments into eradication measures when alien plants such as Impatiens glandulifera occur on their managed sites. Invasive plants species are increasingly representing a problem in terms of management of the regeneration of native tree species. In the context of climate change and the expected increase in disturbances in forest canopies, studies on demographic traits and gap dynamics will become more important in order to identify the early stages of biological invasions by species following the "sit and wait" strategy. Oftentimes, the spread of IAS is promoted by the destruction of natural biotopes resulting in plant-sociological disadvantages for the regeneration of native trees.

\section{DATA AVAILABILITY STATEMENT}

The raw data supporting the conclusions of this article will be made available by the authors, without undue reservation, to any qualified researcher.

\section{AUTHOR CONTRIBUTIONS}

ML and KL conceived of the presented idea. ML and KL developed the theory and performed the computations.

\section{ACKNOWLEDGMENTS}

The BFW is acknowledged for providing the authors with access to its resources. The authors thank Stephan Stockinger for his comments on English language, Janine Oettel for her valuable comments on forest management, and Gerald Schnabel for his creative support on the figures' design, as well as all experts who provided us with additional information. We want to thank two reviewers, whose detailed comments and suggestions substantially improved this manuscript. 


\section{REFERENCES}

(2011). Novel Urban Ecosystems, Biodiversity, and Conservation. Environ. Pollution 159 (8-9), 1974-1983.

(2016). "Planted Forests and Invasive Alien Trees in Europe: A Code for Managing Existing and Future Plantings to Mitigate the Risk of Negative Impacts from Invasions."

Abts, C. (2004). Gebietsfremde Pflanzenarten Der Waldbodenvegetation. LWF Aktuell 45 31-33.

Alston, K. P., and Richardson, D. M. (2006). The Roles of Habitat Features, Disturbance, and Distance from Putative Source Populations in Structuring Alien Plant Invasions at the Urban/Wildland Interface on the Cape Peninsula, South Africa. Biol. Conserv. 132 (2), 183-198. doi: 10.1016/j.biocon. 2006.03.023

Ammer, C., Schall, P., Wördehoff, R., Lamatsch, K., and Bachmann, M. (2011). Does Tree Seedling Growth and Survival Require Weeding of Himalayan Balsam (Impatiens Glandulifera)? Eur. J. For. Res. 130 (1), 107-116. doi: $10.1007 /$ s10342-010-0413-0

Ammer, C. (1996). Impact of Ungulates on Structure and Dynamics of Natural Regeneration of Mixed Mountain Forests in the Bavarian Alps. For. Ecol. Manage. 88 (1-2), 43-53. doi: 10.1016/S0378-1127(96)03808-X

Ashton, I. W., Hyatt, L. A., Howe, K. M., Gurevitch, J., and Lerdau, M. T. (2005). Invasive Species Accelerate Decomposition and Litter Nitrogen Loss in a Mixed Deciduous Forest. Ecol. Appl. 15 (4), 1263-1272. doi: 10.1890/04-0741

Bacher, S., Blackburn, T. M., Essl, F., Genovesi, P., Heikkilä, J., Jeschke, J. M., et al. (2018). Socio-economic Impact Classification of Alien Taxa (SEICAT). Methods Ecol. Evol. 9 (1), 159-168. doi: 10.1111/2041-210X.12844

Barančeková, M., Krojerová-Prokešová, J., and Homolka, M. (2007). Impact of Deer Browsing on Natural and Artificial Regeneration in Floodplain Forest. Folia Zool 56 (4), 354-364.

Becker, T., Dietz, H., Billeter, R., Buschmann, H., and Edwards, P. J. (2005). Altitudinal Distribution of Alien Plant Species in the Swiss Alps. Perspect. Plant Ecology Evol. Systematics 7 (3), 173-183. doi: 10.1016/j.ppees.2005.09.006

Berg, C., Drescher, A., Wagner, V., and Essl, F. (2016). Temporal trends in the invasions of Austrian woodlands by alien trees. Preslia. https://www. researchgate.net/publication/305180772_Temporal_trends_in_the_invasions_ of_Austrian_woodlands_by_alien_trees

Blackburn, T. M., Essl, F., Evans, T., Hulme, P. E., Jeschke, J. M., Kühn, I., et al. (2014). A Unified Classification of Alien Species Based on the Magnitude of Their Environmental Impacts. PloS Biol. 12 (5), e1001850. doi: 10.1371/ journal.pbio. 1001850

Bohn, U., Neuhäusl, R., Gollub, G., Hettwer, C., Neuhäuslová, Z., Raus, T., et al. (2003). Karte Der Natürlichen Vegetation Europas / Map of the Natural Vegetation of Europe (Münster: Landwirtschaftsverlag).

Booth, M. G. (2004). Mycorrhizal Networks Mediate Overstorey-understorey Competition in a Temperate Forest. Ecol. Lett. 7 (7), 538-546. doi: 10.1111/ j.1461-0248.2004.00605.x

Borghetti, M., and Giannini, R. (2009). Natural Regeneration in Woodland Management. Biodiversity Conserv. Habitat Management-Volume I 1, 208.

Braun, M., Schindler, S., and Ess, F. (2016). Distribution and management of invasive alien plant species in protected areas in Central Europe. J. Nat. Conserv. 33, 48-57. doi: 10.1016/j.jnc.2016.07.002

Brooks, M. L., D’antonio, C. M., Richardson, D. M., Grace, J. B., Keeley, J.E., DiTomaso, J. M., et al. (2004). Effects of Invasive Alien Plants on Fire Regimes. BioScience 54 (7), 677-688. doi: 10.1641/0006-3568(2004)054[0677:EOIAPO]2.0.CO;2

Brothers, T. S., and Spingarn, A. (1992). Forest Fragmentation and Alien Plant Invasion of Central Indiana Old-growth Forests. Conserv. Biol. 6 (1), 91-100. doi: 10.1046/j.1523-1739.1992.610091.x

Brundu, G., and Richardson, D. M. (2016). “TEXT BOX II: Code of Conduct on Planted Forest: Recommended Management for in-Troduced and Invasive Tree Species," in Opportunities and Challenges, 420.

Campagnaro, T., Brundu, G., and Sitzia, T. (2018). Five Major Invasive Alien Tree Species in European Union Forest Habitat Types of the Alpine and Continental Biogeographical Regions. J. Nat. Conserv. 43, 227-238. doi: 10.1016/ j.jnc.2017.07.007

Castro-Díez, P., Vaz, A. S., Silva, J. S., Van Loo, M., Alonso, Á., Aponte, C., et al. (2019). Global Effects of Non-native Tree Species on Multiple Ecosystem Services. Biol. Rev. 94 (4), 1477-1501. doi: 10.1111/brv.12511
Chmura, D., and Sierka, E. (2007). The Invasibility of Deciduous Forest Communities after Disturbance: A Case Study of Carex Brizoides and Impatiens Parviflora Invasion. For. Ecol. Manage. 242 (2-3), 487-495. doi: 10.1016/j.foreco.2007.01.083

Chudomelová, M., Hédl, R., Zouhar, V., and Szabó, P. (2017). Open Oakwoods Facing Modern Threats: Will They Survive the next Fifty Years? Biol. Conserv. 210, 163-173. doi: 10.1016/j.biocon.2017.04.017

Chytrý, M., Pyšek, P., Wild, J., Pino, J., Maskell, L. C., and Vilà, M. (2009). European Map of Alien Plant Invasions Based on the Quantitative Assessment across Habitats. Diversity Distributions 15 (1), 98-107. doi: 10.1111/j.14724642.2008.00515.x

Closset-Kopp, D., Chabrerie, O., Valentin, B., Delachapelle, H., and Decocq, G. (2007). When Oskar Meets Alice: Does a Lack of Trade-off in r/K-Strategies Make Prunus Serotina a Successful Invader of European Forests? For. Ecol Manage. 247 (1), 120-130. doi: 10.1016/j.foreco.2007.04.023

Davis, M. A., Wrage, K. J., and Reich, P. B. (1998). Competition between Tree Seedlings and Herbaceous Vegetation: Support for a Theory of Resource Supply and Demand. J. Ecol. 86 (4), 652-661. doi: 10.1046/j.13652745.1998.00087.x

De Lombaerde, ,.E., Verheyen, K., Van Calster, H., and Baeten, L. (2019). Tree Regeneration Responds More to Shade Casting by the Overstorey and Competition in the Understorey than to Abundance per Se. For. Ecol. Manage. 450:117492. doi: 10.1016/j.foreco.2019.117492

Dreiss, L. M., and Volin, J. C. (2013). Influence of Leaf Phenology and Site Nitrogen on Invasive Species Establishment in Temperate Deciduous Forest Understories. For. Ecol. Manage. 296, 1-8. doi: 10.1016/j.foreco.2013.01.031

Dreiss, L. M., Volin, J. C., Closset-Kopp, D., Chabrerie, O., Valentin, B., Delachapelle, H., et al. (2016). Plant Invasions in Temperate Forests: Resistance or Ephemeral Phenomenon? For. Ecol. Manage. 15 (1), 120-130. doi: 10.1016/j.jenvman.2011.01.025

Dyderski, M. K., Gdula, A. K., and Jagodziński, A. M. (2015). 'The Rich Get Richer' Concept in Riparian Woody Species-A Case Study of the Warta River Valley (Poznań, Poland). Urban Forestry Urban Greening 14 (1), 107-114. doi: 10.1016/j.ufug.2014.12.003

Dziub, H. (2019). "MASTERARBEIT Zur Erlangung Des Akademischen Grades Master of Science in Engineering Im Studiengang Technisches Umweltmanagement Und Ökotoxikologie." (Masterthesis, FH Technikum Wien).

Emborg, J. (1998). Understorey Light Conditions and Regeneration with Respect to the Structural Dynamics of a Near-Natural Temperate Deciduous Forest in Denmark. For. Ecol. Manage. 106 (2-3), 83-95. doi: 10.1016/S0378-1127(97) 00299-5

Erdős, L., Kröel-Dulay, G., Bátori, Z., Kovács, B., Németh, C., Kiss, P. J., et al (2018). Habitat heterogeneity as a key to high conservation value in forestgrassland mosaics. Biological Conservation. 226, 72-80. doi: 10.1016/ j.biocon.2018.07.029

Essl, F., Milasowszky, N., and Dirnböck, T. (2011). Plant Invasions in Temperate Forests: Resistance or Ephemeral Phenomenon? Basic Appl. Ecol. 12 (1), 1-9. doi: 10.1016/j.baae.2010.10.003

Ewald, J. (2009). Neophyten in Bayerns Wäldern. LWF Aktuell 732009, 8-11.

Ferréa, C., Zenone, T., Comolli, R., and Seufert, G. (2012). Estimating heterotrophic and autotrophic soil respiration in a semi-natural forest of Lombardy, Italy. Pedobiologia. 55, 285-294. doi: 10.1016/j.pedobi.2012.05.001

Florianová, A., and Münzbergová, Z. (2017). Invasive Impatiens Parviflora Has Negative Impact on Native Vegetation in Oak-Hornbeam Forests. Flora: Morphology Distribution Funct. Ecol. Plants 226, 10-16. doi: 10.1016/ j.flora.2016.11.006

Gaggini, L., Rusterholz, H.-P., and Baur, B. (2017). The invasive plant Impatiens glandulifera affects soil fungal diversity and the bacterial community in forests. Appl. Soil Ecol. 124, 335-343. doi: 10.1016/j.apsoil.2017.11.021

Gaggini, L., Rusterholz, H.-P. P., and Baur, B. (2018). The Invasive Plant Impatiens Glandulifera Affects Soil Fungal Diversity and the Bacterial Community in Forests. Appl. Soil Ecol. 124, 335-343. doi: 10.1016/j.apsoil.2017.11.021

González-Moreno, P., Pino, J., Gassó, N., and Vila, M. (2013). Landscape Context Modulates Alien Plant Invasion in Mediterranean Forest Edges. Biol. Invasions 15 (3), 547-557. doi: 10.1007/s10530-012-0306-x

Grund, K., Conederam, M., Schröder, H., and Walther, G.-R. (2005). The role of fire in the invasion process of evergreen broad-leaved species. Basic Appl. Ecol. 6, 47-56. doi: 10.1016/j.baae.2004.07.005 
Halarewicz, A., and Zołnierz, L. (2014). Changes in the Understorey of Mixed Coniferous Forest Plant Communities Dominated by the American Black Cherry (Prunus Serotina Ehrh.). For. Ecol. Manage. 313, 91-97. doi: 10.1016/ j.foreco.2013.11.006

Haseke, H., and Remschak, C. (2010). "Managementplan Neobiota," in Bericht Der Nationalpark Gesäuse GmbH. Weng.

Hejda, M. (2012). What Is the Impact of Impatiens Parviflora on Diversity and Composition of Herbal Layer Communities of Temperate Forests? PloS One 7 (6), e39571. doi: 10.1371/journal.pone.0039571

Heywood, V. H., and Brunel, S. (2009). Code of Conduct on Horticulture and Invasive Alien Plants (Netherlands: The Hauge).

Hobbs, R. J., and Huenneke, L. F. (1992). Disturbance, Diversity, and Invasion: Implications for Conservation. Conserv. Biol. 6 (3), 324-337. doi: 10.1046/ j.1523-1739.1992.06030324.x

Höfle, R., Dullinger, S., and Essl, F. (2014). Different factors affect the local distribution, persistence and spread of alien tree species in floodplain forests. Basic Appl. Ecol. 15, 426-434. doi: 10.1016/j.baae.2014.07.007

Howe, H. F., and Smallwood, J. (1982). Ecology of Seed Dispersal. Annu. Rev. Ecol. Systematics 13 (1), 201-228. doi: 10.1146/annurev.es.13.110182.001221

IUCN Council (2000). "Guidelines for the Prevention of Biodiversity Loss Caused by Alien Invasive Species." in Prepared by IUCN SSC Invasive Species Specialist Group (ISSG) Approved by 51st Meeting IUCN Council Gland Switzerland. 1, $12-25$.

Jarčuška, B., Slezák, M., Hrivnák, R., and Senko, D. (2016). Invasibility of Alien Impatiens Parviflora in Temperate Forest Understories. Flora 224, 14-23. doi: 10.1016/j.flora.2016.06.005

Joly, M., Bertrand, P., Gbangou, R. Y., White, M. C., Dubeé, J., and Lavoie, C. (2011). Paving the Way for Invasive Species: Road Type and the Spread of Common Ragweed (Ambrosia Artemisiifolia). Environ. Manage. 48 (3), 514522. doi: 10.1007/s00267-011-9711-7

Kalusová, V., Chytrý, M., Kartesz, J. T., Nishino, M., and Pyšek, P. (2013). Where Do They Come from and Where Do They Go? European Natural Habitats as Donors of Invasive Alien Plants Globally. Diversity Distributions 19 (2), 199214. doi: $10.1111 /$ ddi. 12008

Kerri, S., Sigg, D., Baird, G., Chadburn, C., and Starkl-Moser, M. (2016). "Soil Movement: Contamination and Invasive Species."

Kirby, K., and Watkins, C. (2015). Europe"s Changing Woods and Forests: From Wildwood to Managed Landscapes (Oxfordshire: CABI Publishing).

Knapp, L. B., and Canham, C. D. (2000). Invasion of an Old-Growth Forest in New York by Ailanthus Altissima: Sapling Growth and Recruitment in Canopy Gaps. J. Torrey Botanical Soc., 127, 307-315. doi: 10.2307/3088649

Knüsel, S., Conedera, M., Rigling, A., Fonti, P., and Wunder, J. (2015). A TreeRing Perspective on the Invasion of Ailanthus Altissima in Protection Forests. For. Ecol. Manage. 354, 334-343. doi: 10.1016/j.foreco.2015.05.010

Kopeć, D., Ratajczyk, N., Wolańska-Kamińska, A., Walisch, M., and Kruk, A. (2014). Floodplain Forest Vegetation Response to Hydroengineering and Climatic Pressure - A Five Decade Comparative Analysis in the Bzura River Valley (Central Poland). For. Ecol. Manage. 314, 120-130. doi: 10.1016/ j.foreco.2013.11.033

Kowarik, I. (2010). Biologische Invasionen: Neophyten Und Neozoen in Mitteleuropa; 77 Tabellen /Ingo Kowarik. Mit Beitr. von Wolfgang Rabitsch. Ed. W. Rabitsch (wesent. Stuttgart: Ulmer).

Kutnar, L., and Pisek, R. (2013). Non-Native and Invasive Tree Species in the Slovenian Forests. Gozdarski Vestnik 71 (9), 402-417.

Lake, J. C., and Leishman, M. R. (2004). Invasion Success of Exotic Plants in Natural Ecosystems: The Role of Disturbance, Plant Attributes and Freedom from Herbivores. Biol. Conserv. 117 (2), 215-226. doi: 10.1016/S0006-3207(03)00294-5

Lapin, K., Oettel, J., Steiner, H., Langmaier, M., Sustic, D., Starlinger, F., et al. (2019). Invasive Alien Plant Species in Unmanaged Forest Reserves, Austria. NeoBiota 48 (48), 71-96. doi: 10.3897/neobiota.48.34741

Łapok, R., Borkowska, L, Lembicz, M., Jensen, K., and Kasprzykowski, Z. (2018). A narrow-gauge railway in the Białowieża Primeval Forest as a corridor for nonnative species migration. Flora. 240, 40-47. doi: 10.1016/j.flora.2018.01.002

Laube, J., Sparks, T. H., Bässler, C., and Menzel, A. (2015). Small Differences in Seasonal and Thermal Niches Influence Elevational Limits of Native and Invasive Balsams. Biol. Conserv. 191, 682-691. doi: 10.1016/j.biocon.2015. 08.019
Lee, C.-S., Cho, H.-J., and Yi, H. (2004). Stand Dynamics of Introduced Black Locust (Robinia Pseudoacacia L.) Plantation under Different Disturbance Regimes in Korea. For. Ecol. Manage. 189 (1-3), 281-293. doi: 10.1016/ j.foreco.2003.08.012

Maringer, J., Wohlgemuth, T., Neff, C., Pezzatti, G. B., and Conedera, M. (2012). Post-Fire Spread of Alien Plant Species in a Mixed Broad-Leaved Forest of the Insubric Region. Flora - Morphology Distribution Funct. Ecol. Plants 207 (1), 19-29. doi: 10.1016/j.flora.2011.07.016

Martin, P. H., Canham, C. D., and Marks, P. L. (2009). Why Forests Appear Resistant to Exotic Plant Invasions: Intentional Introductions, Stand Dynamics, and the Role of Shade Tolerance. Front. Ecol. Environ. 7 (3), 142-149. doi: 10.1890/070096

McEwan, R. W., Birchfield, M.K., Schoergendorfer, A., and Arthur, M. A. (2009). Leaf Phenology and Freeze Tolerance of the Invasive Shrub Amur Honeysuckle and Potential Native Competitors. J. Torrey Botanical Soc. 136 (2), 212-221. doi: 10.3159/08-RA-109.1

Medvecká, J., Jarolímek, I., Hegedüšová, K., Škodová, I., Bazalová, D., Botková, K., et al. (2018). Forest Habitat Invasions-Who with Whom, Where and Why. For. Ecol. Manage. 409, 468-478. doi: 10.1016/j.foreco.2017.08.038

Montoro Girona, M., Morin, H., Lussier, J.-M., and Walsh, D. (2016). Radial Growth Response of Black Spruce Stands Ten Years after Experimental Shelterwoods and Seed-Tree Cuttings in Boreal Forest. Forests 7 (10), 240. doi: 10.3390/f7100240

Montoro Girona, M., Rossi, S., Lussier, J.-M., Walsh, D., and Morin, H. (2017). Understanding Tree Growth Responses after Partial Cuttings: A New Approach. PloS One 12 (2), e0172653. doi: 10.1371/journal.pone.0172653

Montoro Girona, M., Lussier, J.-M., Morin, H., and Thiffault, N. (2018). Conifer Regeneration after Experimental Shelterwood and Seed-Tree Treatments in Boreal Forests: Finding Silvicultural Alternatives. Front. Plant Sci. 9, 1145. doi: 10.3389/fpls.2018.01145

Montoro Girona, M., Morin, H., Lussier, J.-M., and Ruel, J.-C. (2019). PostCutting Mortality Following Experimental Silvicultural Treatments in Unmanaged Boreal Forest Stands. Front. Forests Global Change 2, 4. doi: $10.3389 /$ ffgc. 2019.00004

Moravcová, L., Perglová, I., Pyšek, P., Jarošík, V., and Pergl, J. (2005). Effects of fruit position on fruit mass and seed germination in the alien species Heracleum mantegazzianum (Apiaceae) and the implications for its invasion. Acta Oecologica 28, 1-10. doi: 10.1016/j.actao.2005.01.004

Motard, E., Muratet, A., Clair-Maczulajtys, D., and MacHon, N. (2011). Does the Invasive Species Ailanthus Altissima Threaten Floristic Diversity of Temperate Peri-Urban Forests? Comptes Rendus - Biologies 334 (12), 872-879. doi: 10.1016/j.crvi.2011.06.003

Muscolo, A., Bagnato, S., Sidari, M., and Mercurio, R. (2014). A Review of the Roles of Forest Canopy Gaps. J. Forestry Res. 25 (4), 725-736. doi: 10.1007/ s11676-014-0521-7

Navarro, L., Morin, H., Bergeron, Y., and Girona, M. M. (2018). Changes in Spatiotemporal Patterns of 20th Century Spruce Budworm Outbreaks in Eastern Canadian Boreal Forests. Front. Plant Sci. 9, 1905. doi: 10.3389/ fpls.2018.01905

Nobis, A., Żmihorski, M., and Kotowska, D. (2016). Linking the Diversity of Native Flora to Land Cover Heterogeneity and Plant Invasions in a River Valley. Biol. Conserv. 203, 17-24. doi: 10.1016/j.biocon.2016.08.032

Nobis, A., Rola, K., and Węgrzyn, M. (2017). Detailed Study of a River Corridor Plant Distribution Pattern Provides Implications for River Valley Conservation. Ecol. Indic. 83, 314-322. doi: 10.1016/j.ecolind.2017.07.040

Nováková, J. (2008). Vegetation Changes in Prague's Suburban Forest during the Last 40 Years - Human Impact and Legislative Protection. Urban Forestry Urban Greening 7 (4), 301-314. doi: 10.1016/j.ufug.2008.02.006

Pěknicová, J., and Berchová-Bímová, K. (2016). Application of species distribution models for protected areas threatened by invasive plants. J. Nat. Conserv. 34, 1-7. doi: 10.1016/j.jnc.2016.08.004

Petrášová, M., Jarolímek, I., and Medvecká, J. (2013). Neophytes in Pannonian Hardwood Floodplain Forests - History, Present Situation and Trends. For. Ecol. Manage. 308, 31-39. doi: 10.1016/j.foreco.2013.07.041

Potgieter, L. J., Gaertner, M., Farrell, P. J. O., and Richardson, D. M. (2019). Perceptions of Impact: Invasive Alien Plants in the Urban Environment. J. Environ. Manage. 229, 76-87. doi: 10.1016/j.jenvman.2018.05.080 
Pötzelsberger, E., Lapin, K., Brundu, G., Adriaens, T., Andonovski, V., Andrašev, S., et al. (2020). Mapping the Patchy Legislative Landscape of Non-Native Tree Species in Europe. Forestry: Int. J. For. Res. 93, 567-586. doi: 10.1093/forestry/cpaa009

Pyšek, P., and Prach, K. (1995). Invasion dynamics of Impatiens glandulifera - A century of spreading reconstructed. Biol. Conserv. 74, 41-48. doi: 10.1016/ 0006-3207(95)00013

Pyšek, P., Jarošík, V., and Pergl, J. (2011). Alien plants introduced by different pathways differ in invasion success: unintentional introductions as a threat to natural areas. PloS One 6 (9), e24890.

Pyšek, P., Richardson, D. M., Rejmánek, M., Webster, G. L., Williamson, M., and Kirschner, J. (2004). Alien Plants in Checklists and Floras: Towards Better Communication between Taxonomists and Ecologists. Taxon 53 (1), 131-143. doi: $10.2307 / 4135498$

R Core Team (2017). "R: A Language and Environment for Statistical Computing." (Vienna, Austria: R Foundation for Statistical Computing).

Radovanović, N., Kuzmanović, N., Vukojičić, S., Lakušić, D., and Jovanović, S. (2017). Floristic Diversity, Composition and Invasibility of Riparian Habitats with Amorpha Fruticosa: A Case Study from Belgrade (Southeast Europe). Urban Forestry Urban Greening 24, 101-108. doi: 10.1016/j.ufug.2017.04.006

Radtke, A., Ambraß, S., Zerbe, S., Tonon, G., Fontana, V., and Ammer, C. (2013). Traditional Coppice Forest Management Drives the Invasion of Ailanthus Altissima and Robinia Pseudoacacia into Deciduous Forests. For. Ecol. Manage. 291, 308-317. doi: 10.1016/j.foreco.2012.11.022

Raghubanshi, A. S., and Tripathi, A. (2009). Effect of Disturbance, Habitat Fragmentation and Alien Invasive Plants on Floral Diversity in Dry Tropical Forests of Vindhyan Highland: A Review. Trop. Ecol. 50 (1), 57. doi: 10.1155/2011/297097

Rahmonov, O. (2009). The Chemical Composition of Plant Litter of Black Locust (Robinia Pseudoacacia L.) and Its Ecological Role in Sandy Ecosystems. Shengtai Xuebao/ Acta Ecologica Sin. 29 (4), 237-243. doi: 10.1016/ j.chnaes.2009.08.006

Regulation, E. U. (2014). Regulation (EU) No 1143/2014 of the European Parliament and of the Council of 22 October 2014 on the Prevention and Management of the Introduction and Spread of Invasive Alien Species. Off. J. Eur. Union 57 (317), 35.

Rejmánek, M. (2014). Invasive Trees and Shrubs: Where Do They Come from and What We Should Expect in the Future? Biol. Invasions 16 (3), 483-498. doi: 10.1007/s10530-013-0603-z

Ricard, J.-P., Messier, C., Delagrange, S., and Beaudet, M. (2003). Do Understory Sapling Respond to Both Light and Below-Ground Competition?: A Field Experiment in a North-Eastern American Hardwood Forest and a Literature Review. Ann. For. Sci. 60 (8), 749-756. doi: 10.1051/forest:2003069

Richardson, D. M., Pyšek, P., Rejmánek, M., Barbour, M. G., Dane Panetta, F., and West, C. J. (2000). Naturalization and Invasion of Alien Plants: Concepts and Definitions. Diversity Distributions 6 (2), 93-107. doi: 10.1046/j.14724642.2000.00083.x

Richardson, D. M., Holmes, P. M., Esler, K. J., Galatowitsch, S. M., Stromberg, J. C., Kirkman, S. P., et al. (2007). Riparian Vegetation: Degradation, Alien Plant Invasions, and Restoration Prospects. Diversity Distributions 13 (1), 126139. doi: $10.1111 / j .1366-9516.2006 .00314 . x$

Rouifed, S., Piola, F., and Spiegelberger, T. (2014). Invasion by Fallopia spp. in a French upland region is related to anthropogenic disturbances. Basic Appl. Ecol. 15, 435-443. doi: 10.1016/j.baae.2014.07.005

Roy, H. E., Bacher, S., Essl, F., Adriaens, T., Aldridge, D. C., Bishop, J. D.D., et al. (2019). Developing a List of Invasive Alien Species Likely to Threaten Biodiversity and Ecosystems in the European Union. Global Change Biol. 25 (3), 1032-1048. doi: 10.1111/gcb.14527

Royo, A. A., and Carson, W. P. (2008). Direct and Indirect Effects of a Dense Understory on Tree Seedling Recruitment in Temperate Forests: Habitat-Mediated Predation versus Competition. Can. J. For. Res. 38 (6), 1634-1645. doi: 10.1139/X07-247

Ruckli, R., Rusterholz, H.-P., and Baur, B. (2014). Invasion of an Annual Exotic Plant into Deciduous Forests Suppresses Arbuscular Mycorrhiza Symbiosis and Reduces Performance of Sycamore Maple Saplings. For. Ecol. Manage. 318, 285-293. doi: 10.1016/j.foreco.2014.01.015

Rupp, M., Palm, T., and Michiels, H.-G. (2017). Die Kermesbeere - Eine Invasive Art in Lichten Wäldern. AFZ-Der Wald 9, 38-42.

Rusterholz, H.-P., Salamon, J. A., Ruckli, R., and Baur, B. (2014). Effects of the Annual Invasive Plant Impatiens Glandulifera on the Collembola and Acari Communities in a Deciduous Forest. Pedobiologia 57 (4-6), 285-291. doi: 10.1016/j.pedobi.2014.07.001
Rusterholz, H.-P., Küng, J., and Baur, B. (2017). Experimental Evidence for a Delayed Response of the Above-Ground Vegetation and the Seed Bank to the Invasion of an Annual Exotic Plant in Deciduous Forests. Basic Appl. Ecol. 20, 19-30. doi: 10.1016/j.baae.2017.02.004

Rusterholz, H.-P., Schneuwly, J., and Baur, B. (2018). Invasion of the Alien Shrub Prunus Laurocerasus in Suburban Deciduous Forests: Effects on Native Vegetation and Soil Properties. Acta Oecologica 92, 44-51. doi: 10.1016/j.actao.2018.08.004

Sanderson, L. A., McLaughlin, J. A., and Antunes, P. M. (2012). The Last Great Forest: A Review of the Status of Invasive Species in the North American Boreal Forest. Forestry 85 (3), 329-340. doi: 10.1093/forestry/cps033

Sanford, N. L., Harrington, R. A., and Fownes, J. H. (2003). Survival and Growth of Native and Alien Woody Seedlings in Open and Understory Environments. For. Ecol. Manage. 183 (1-3), 377-385. doi: 10.1016/S0378-1127(03)00141-5

Schiffleithner, V., and Essl, F. (2016). Is It Worth the Effort? Spread and Management Success of Invasive Alien Plant Species in a Central European National Park. NeoBiota 31, 43-61. doi: 10.3897/neobiota.31.8071

Schmiedel, D., and Tackenberg, O. (2013). Hydrochory and water induced germination enhance invasion of Fraxinus pennsylvanica. For. Ecol. Manage. 304, 437-443. doi: 10.1016/j.foreco.2013.04.027

Schmiedel, D., Huth, F., and Wagner, S. (2013). Using Data from Seed-Dispersal Modelling to Manage Invasive Tree Species: The Example of Fraxinus Pennsylvanica Marshall in Europe. Environ. Manage. 52 (4), 851-860. doi: 10.1007/s00267-013-0135-4

Schnitzler, A. (1994). Conservation of Biodiversity in Alluvial Hardwood Forests of the Temperate Zone. The Example of the Rhine Valley. For. Ecol. Manage. 68 (2-3), 385-398. doi: 10.1016/0378-1127(94)90059-0

Schultze, J., Gärtner, S., Bauhus, J., Meyer, P., and Reif, A. (2014). Criteria to Evaluate the Conservation Value of Strictly Protected Forest Reserves in Central Europe. Biodiversity Conserv. 23 (14), 3519-3542. doi: 10.1007/s10531-014-0787-2

ScienceDirect (2019). "ScienceDirect."

Sebert-Cuvillier, E., Paccaut, F., Chabrerie, O., Endels, P., Goubet, O., and Decocq, G. (2007). Local Population Dynamics of an Invasive Tree Species with a Complex Life-History Cycle: A Stochastic Matrix Model. Ecol. Modelling 201 (2), 127-143. doi: 10.1016/j.ecolmodel.2006.09.005

Seidl, R., Thom, D., Kautz, M., Martin-Benito, D., Peltoniemi, M., Vacchiano, G., et al. (2017). Forest Disturbances under Climate Change. Nat. Climate Change 7 (6), 395-402. doi: 10.1038/nclimate3303

Seipel, T., Alexander, J. M., Edwardsm, P. J., and Kueffer, C. (2016). Range limits and population dynamics of non-native plants spreading along elevation gradients. Perspect. Plant Ecol. 20, 46-55. doi: 10.1016/j.ppees.2016.04.001

Shackleton, R. T., Biggs, R., Richardson, D. M., and Larson, B. M.H. (2018). SocialEcological Drivers and Impacts of Invasion-Related Regime Shifts: Consequences for Ecosystem Services and Human Wellbeing. Environ. Sci. Policy 89, 300-314. doi: 10.1016/j.envsci.2018.08.005

Sitzia, T., Campagnaro, T., Kowarik, I., and Trentanovi, G. (2016). Using Forest Management to Control Invasive Alien Species: Helping Implement the New European Regulation on Invasive Alien Species. Biol. Invasions 18 (1), 1-7. doi: 10.1007/s10530-015-0999-8

Sjöman, H., Morgenroth, J., Sjöman, J. D., Sæbø, A., and Kowarik, I. (2016). Diversification of the Urban Forest-Can We Afford to Exclude Exotic Tree Species? Urban Forestry Urban Greening 18, 237-241. doi: 10.1016/j.ufug.2016.06.011

Staska, B., Essl, F., and Samimi, C. (2014). Density and Age of Invasive Robinia Pseudoacacia Modulate Its Impact on Floodplain Forests. Basic Appl. Ecol. 15 (6), 551-558. doi: 10.1016/j.baae.2014.07.010

Svoboda, M., Fraver, S., Janda, P., Bače, R., and Zenáhlíková, J. (2010). Natural Development and Regeneration of a Central European Montane Spruce Forest. For. Ecol. Manage. 260 (5), 707-714. doi: 10.1016/j.foreco.2010.05.027

Terwei, A., Zerbe, S., Zeileis, A., Annighöfer, P., Kawaletz, H., Mölder, I., et al. (2013). Which Are the Factors Controlling Tree Seedling Establishment in North Italian Floodplain Forests Invaded by Non-Native Tree Species? For. Ecol. Manage. 304, 192-203. doi: 10.1016/j.foreco.2013.05.003

Thurm, E. A., Hernandez, L., Baltensweiler, A., Ayan, S., Rasztovits, E., Bielak, K., et al. (2018). Alternative tree species under climate warming in managed European forests. For. Ecol. Manage. 430, 485-497. doi: 10.1016/j.foreco.2018.08.028

The Plant List (2013). "The Plant List." Available at: http://www.theplantlist.org/.

Tinya, F., Márialigeti, S., Bidló, A., and Ódor, P. (2019). Environmental Drivers of the Forest Regeneration in Temperate Mixed Forests. For. Ecol. Manage. 433, 720-728. doi: 10.1016/j.foreco.2018.11.051 
Vacchiano, G., Meloni, F., Ferrarato, M., Freppaz, M., Chiaretta, G., Motta, R., et al. (2016). Frequent Coppicing Deteriorates the Conservation Status of Black Alder Forests in the Po Plain (Northern Italy). For. Ecol. Manage. 382, 31-38. doi: 10.1016/j.foreco.2016.10.009

Vaz, A. S., Kueffer, C., Kull, C. A., Richardson, D. M., Vicente, J. R., Kühn, I., et al. (2017). Integrating Ecosystem Services and Disservices: Insights from Plant Invasions. Ecosystem Serv. 23, 94-107. doi: 10.1016/j.ecoser. 2016.11.017

Vaz, A. S., Castro-Díez, P., Godoy, O., Alonso, Á., Vilà, M., Saldaña, A., et al. (2018). An Indicator-Based Approach to Analyse the Effects of Non-Native Tree Species on Multiple Cultural Ecosystem Services. Ecol. Indic. 85, 48-56. doi: 10.1016/j.ecolind.2017.10.009

Vera, F. W. M. (2000). Grazing Ecology and Forest History (CABI publishing).

Vilà, M., Espinar, J. L., Hejda, M., Hulme, P. E., Jarošík, V., Maron, J. L., et al. (2011). Ecological Impacts of Invasive Alien Plants: A Meta-analysis of Their Effects on Species, Communities and Ecosystems. Ecol. Lett. 14 (7), 702-708. doi: 10.1111/j.1461-0248.2011.01628.x

Villamagna, A. M., and Murphy, B. R. (2010). Ecological and Socio-economic Impacts of Invasive Water Hyacinth (Eichhornia Crassipes): A Review. Freshwater Biol. 55 (2), 282-298. doi: 10.1111/j.1365-2427.2009.02294.x
Wagner, V., Chytrý, M., Jiménez-Alfaro, B., Pergl, J., Hennekens, S., Biurrun, I., et al. (2017). Alien Plant Invasions in European Woodlands. Diversity Distributions 23 (9), 969-981. doi: 10.1111/ddi.12592

Woziwoda, B., Krzyżanowska, A., Dyderski, M. K., Jagodziński, A. M., and Stefańska-Krzaczek, E. (2018). Propagule Pressure, Presence of Roads, and Microsite Variability Influence Dispersal of Introduced Quercus Rubra in Temperate Pinus Sylvestris Forest. For. Ecol. Manage. 428, 35-45. doi: 10.1016/ j.foreco.2018.06.033

WWF (2020). "Terrestrial Ecoregions."

Conflict of Interest: The authors declare that the research was conducted in the absence of any commercial or financial relationships that could be construed as a potential conflict of interest.

Copyright (c) 2020 Langmaier and Lapin. This is an open-access article distributed under the terms of the Creative Commons Attribution License (CC BY). The use, distribution or reproduction in other forums is permitted, provided the original author(s) and the copyright owner(s) are credited and that the original publication in this journal is cited, in accordance with accepted academic practice. No use, distribution or reproduction is permitted which does not comply with these terms. 